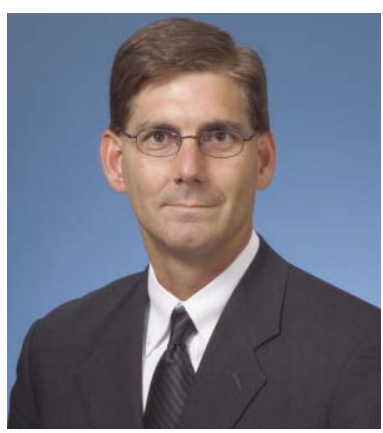

\section{Securing Funds for Research or Product Development}

There's the old marketing joke, "I used to be a salesman, but I got tired of receiving the same three orders: get out, stay out, and don't come back." For new professors, industry scientists and engineers, and government employees, marketing your research is a difficult, time-consuming, frustrating, and thankless exercise. Unless you work for a resource sponsor such as the National Science Foundation, the Office of Naval Research, or the National Institutes of Health, chances are good that you will have to market yourself. In addition, your success as a new professor or new industry/government employee may depend on the amount of research funding or product development funding that you secure. In most universities, tenure decisions are heavily weighted on publications and research funding. I have always thought that a required course in science and engineering curriculum should be how to market ideas and secure funding to pursue those ideas.

My own experience as a new professor was extremely frustrating because I worked hard at writing research proposals and yet secured very few (and they were for very small amounts of funding). My process was to comb the solicitations in the office of sponsored research (before Internet proliferation) and determine which call for proposals I would pursue. I would spend a few weeks writing a detailed research proposal with what I considered outstanding ideas. I would then send off the proposal by registered mail, ensuring that it reached the sponsoring agency prior to the deadline, so that I was certain that my proposal would be given serious consideration. More than nine out of ten proposals were returned with high marks (some of them with perfect marks) and a notice of "declined for funding."

In the years since, I have met new professors, postdoctorates, and new scientists and engineers who use the same approach that I did many years ago. ... . and I have some pointers for you. First, do not send off a proposal unless you have first met the program manager, shaken that program manager's hand, and made sure that program manager knows your name and who you are before you leave. In short, introduce yourself! I know that most scientists and engineers are introverts, but this simple action increases your chances to secure funding significantly. There is always a toss-up on research-proposal ratings (the good ones end up on top, but there is not enough funding to award them all) and funding someone you have met is easier than funding an unknown. Besides, if you are going to be a well-known scientist or engineer, then you need to get out and meet the resource sponsor players in your field anyway.

Second, understand your prospective sponsor's needs. If you make time to visit a resource sponsor and/or program manager, then it is worth asking what their program needs are and what they are interested in with respect to goals. And then, listen. All program managers want to have successful programs, and if you help them be successful, then there is a good chance that you will build a long-term relationship with that person. If you make them look good, they will reward you with further research funding.

Third, develop what many people call the "elevator talk." The elevator talk is three or so slides that present your concept, your approach, and what you will provide at the end of the effort. This proposal should be short enough that when you get in an elevator, you can convince the program manager to fund it before the door opens to get out. Many funded proposals start out this way because program managers are in high demand (everyone wants their money), so you can usually only get a little of their time and even less of their interest. If they are interested in your elevator talk, then they will make time for a more detailed proposal or presentation. You also need to emphasize why it is important (not just why it is important in general, but why is it important for this particular program manager). You are helping them solve their problems.

Fourth, be persistent. If your proposal is not funded, move on to the next funding agency. And, if the opportunity arises, resubmit the proposal to the agency that previously rejected the proposal. Sometimes, it takes a program manager awhile to warm up to a particular idea or concept.

Finally, be excited about your proposal while you describe it. I have a close university friend who secures around 2.5 million dollars a year in research funding. His enthusiasm is endless and he is a hero at his university. The university cannot reward him with enough titles and salary dollars. A big key to his success is that his attitude is so positive that it is contagious. I have seen his sponsors become excited about his work because he talks about his proposals and his results like a kid in a candy store. We can all take a lesson from his success.

Any accomplished scientist or engineer, at some point, has to market his or her work. Invariably, there are many strategies to secure funding for research or product development, but meeting and developing relationships with program managers is a strategy that works. With some effort, you can overcome the "get out, stay out, and don't come back" response.

Ronald G. Driggers Editor

PS: What does securing funds for research or product development have to do with Optical Engineering? Most research papers begin with secured funding! 